\title{
Spatial distribution of agricultural land carrying capacity in Purworejo Regency
}

\author{
Sudrajat Sudrajat", Ananda Trisakti Nugroho, Elvita Savitri, and Ismi Nuari Puspitaningrum \\ Geography and Environmental Sciences, Departement of Environmental Geography, Faculty of Geography, Universitas Gadjah \\ Mada, Indonesia
}

\begin{abstract}
The increasing population in Purworejo Regency has a negative impact on the availability of agricultural land. As a result, available agricultural land is decreasing it's carrying capacity, in producing food for the population. Based on these problems, the study was carried out to analyze the spatial temporally distribution trends of the carrying capacity of agricultural land in the Purworejo Regency area from 2009-2018. The study used secondary data 2009-20018 and analyzed descriptively qualitatively. Spatially the results of the study found that there were variations in the spatial distribution patterns of the carrying capacity of agricultural land in Purworejo Regency from 2009-2018, while judging by the trend, there was a tendency for the carrying capacity of agricultural land in each sub-district, the trend of which increased, decreased and some remained. The results of this study also found that the carrying capacity of agricultural land in each sub-district in Purworejo Regency was between 1- $\leq 2.46$. If the trend of decreasing the carrying capacity of agricultural land is allowed to continue, the ability of the sub-district to produce food will decrease, so that the availability of local food will decrease. For this reason, it is natural for the Purworejo Regency Government to adopt a policy to control agricultural land so that the sub-districts that become food storage can be maintained.
\end{abstract}

Keywords: Agricultural land, paddy field, carrying capacity, population and social-economic.

\section{Introduction}

Use high population growth has an impact on the high demand for land for non-agricultural land use. In fact, the available agricultural land is decreasing, so that a lot of agricultural land has begun to be converted to land for socio-economic infrastructure needs of the population. Declining agricultural land will ultimately lead to a decrease in the carrying capacity of agricultural land and will have an impact on low agricultural production [1-3]. The phenomenon of decreasing carrying capacity of agricultural land in a region, is inseparable from the influence of changes in the socio-cultural system of society and the development of its population $[4,5]$. The reduced carrying capacity of agricultural land does not rule out the possibility of affecting agricultural sustainability, because farmers no longer feel sufficient to survive with increasingly narrow agricultural land [6$8]$.

Spatially the imbalance between the population and the carrying capacity of agricultural land in certain regions occurs, because these areas have high population density dynamics and very rapid socioeconomic development. Usually this area is characterized by relatively small land tenure by farmers, sporadic changes in activities from agriculture to nonagriculture, population migration and urbanization processes continue to increase, connectivity and social relations between villages and cities are very high, and the emergence of diversity in land use, both for settlements residents as well as for trade, service, industrial and other areas $[9,10]$. This phenomenon has brought changes in farmers commitment to release their agricultural land because the land does not provide enough economic value to meet their daily needs. Even with the low regeneration of farmers due to changes in orientation of young generations of farmers in choosing jobs, will further reduce the attractiveness of agriculture for the generation of young people [1]. As a result, the sustainability of agriculture supported by adequate agricultural land will be very worrying in the future. Moreover, if the imbalance between land availability and population is not immediately resolved, the population pressure on agricultural land will be even stronger. In the end, agricultural land will no longer be able to meet food needs to support the lives of the population in a sustainable manner $[11,12]$.

\section{Research method}

This research was conducted in Purworejo Regency. The basis for consideration of taking Purworejo Regency include: Agricultural land area still $86.7 \%$; as one of the rice barns in Central Java Province, directly adjacent to Yogyakarta International Airport (YIA) and

\footnotetext{
* Corresponding author: sdrajat@ugm.ac.id
} 
the number of farmers who depend on the agricultural sector is still quite high.

This research uses secondary data. Data used is the data of Purworejo Regency in Numbers from the Central Statistics Agency 2019. The research varibel is the supporting capacity of agricultural land. Data that used to harvest area, number of population, minimum physical needs (KFM) and rice field productivity. To calculate the carrying capacity of agriculture land using equations developed in Odum theory [8]:

$$
\partial=\frac{L p / P d}{K F M / P r}
$$

Description:

$$
\begin{array}{ll}
\partial & : \text { Carrying capacity of agricultural land } \\
L p & : \text { Harvested area (hectares) } \\
P d & : \text { Population (inhabitants) } \\
K F M & : \text { Minimum Physical Needs (kg/capita/year) } \\
\operatorname{Pr} & \text { : Average land production per hectare } \\
& \text { (kg/hectares) }
\end{array}
$$

In this research, the minimum physical need (KFM) is $320 \mathrm{~kg} / \mathrm{capita} /$ year for the village and 480 $\mathrm{kg} /$ capita/year for the city. The difference in KFM values between rural and urban areas is expected to have a calculation result that is closer to the actual conditions. The carrying capacity of agricultural land is categorized into 3 categories, namely: (1) class $I=\partial>2.46$ gives the meaning of the analyzed region capable of selfsufficiency of food and become a viable source of livelihood for their population; (2) class II $=1 \leq \partial \leq 2.46$ gives the meaning of the analyzed region able to selfsufficiency food but not yet a viable source of livelihood for their population; and class III $=\partial<1$ gives the meaning of the analyzed region not yet capable of food self-sufficiency [13-15].

\section{Result and discussion}

\subsection{Spatial disribusi of populatian in Purworejo Disctric}

Purworejo Regency has an area of 103481 ha which is administratively divided into 16 sub-districts, 25 urban villages and 469 villages. If in 2009 the population of Purworejo Regency was 782662 people. But in 20018 decreased to 716477 inhabitants [16]. Figure 2 shows a decrease in the population of Purworejo Regency the biggest occurred in 2010 and 2011, but again increased in 2012. Although since 2012 it has increased again, however the increase up to 2018 is relatively low at only $0.392 \% \mathrm{yr}^{-1}$. Declining population in 2010 , caused by demographic and non-demographic factors. From demographic factors the decrease in the population of Purworejo Regency happened because of the success of the government in suppressing the birth rate so the population growth from the aspect of birth is low.

On the other side, reducing the population in Purworejo Regency because out migration is greater than in migration. The high migration of residents who came out of Purworejo Regency caused by economic factors, both personally and through independent transmigration channels. From the non-demographic side, the decline of population in Purworejo Regency caused by natural disasters such as landslides and other disasters that cause casualties. More clearly the trend of population growth in Purworejo Regency from 20092018 can be seen in the following Figure 1.

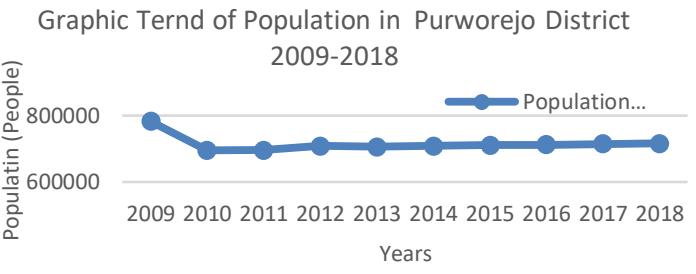

Fig. 1. Graphic trend of population in Purworejo Regency 2009-2018

Spatially the distribution of population in Purworejo Regency spreads in 16 sub-districts with varying amounts. If seen in Figure 2 related to the trend of variations in distribution, it appears that the number of population decreasing in number from 2009 to 2010 is in the sub-districts of Purworejo, Bayan, Kutoarjo, Pituruh, Kemiri, Bruno, Gebang, Loano and Bener, while the sub-districts with increasing population there in the sub-districts of Grabag, Ngombol, Purwodadi, Bagelen, Kaligesing, Banyuurip and Butuh. More clearly the trend of increase and decrease in population in each sub-district in Purworejo Regency from 2009 to 2010 can be seen in Figure 2 below.

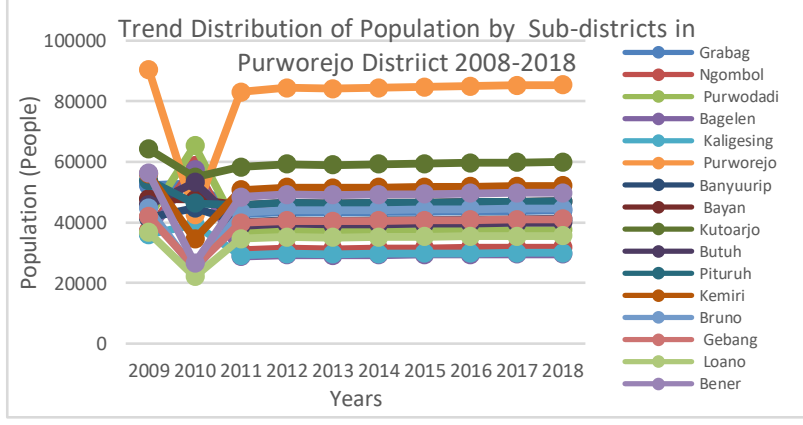

Fig. 2. Trend distribution of population by sub-districts in Purworejo Regency 2009-2018.

Figure 2 also shows an interesting trend from 2010 to 2011, because there are a number of sub-districts whose population has declined from 2010 to 2011, but there are also sub-districts where the population has increased, and some even have quite sharp increases. The sub-districts that increased in population from 2010 to 2011 were Sub-district of Purworejo, Kutoarjo, Kemiri, Bruno, Gebang, Loano and Bener, while the sub-districts that declined in population were the Subdistricts of Grabag, Ngombol, Purwodadi, Bagelen, Kaligesing, Banyuurip, Bayan, Butuh and Pituruh. Meanwhile, the trend of population growth from 20122018 in each sub-district in Purworejo Regency tends to be stable or does not show any fluctuating variation.

The phenomenon of population development trends which is quite varied in 2009-2011 reflects the dynamics of the population in the sub-district is not yet stable, 
because it is influenced by demographic and nondemographic factors. On the contrary, in 2012-2018 in each sub-district in Purworejo Regency it can be said that there has been a stable demographic or nondemographic process that has an influence on population development trends. Developing a dynamic population will ultimately affect the need for land, both for agriculture and for non-agriculture. If the increase for land demand is not met, then the conversion of agricultural land will occur and ultimately will reduce the carrying capacity of agricultural land. Decreasing the carrying capacity of agricultural land means that it will reduce food production and ultimately the sustainability of land carrying capacity is difficult to maintain $[1,8]$.

\subsection{Spatial disribution of agriculture land in Purworejo Regency}

In general land use in Purworejo Regency is grouped into 2 (two) types; namely the use of land for agriculture and non-agriculture. Land use for agriculture are 2 (two) types; namely paddy fields and non-paddy fields. The types of paddy fields are are 3 (three) types; namely rain-fed rice fields, technically irrigated rice fields and tidal paddy fields. Meanwhile, for non-paddy fields, the land is divided into 8 (eight) types, namely upland land, farmland, plantation land, community forest land, state forest land, grassland land, idle land or temporary land not cultivated and garden land. For non-agricultural land consists of residential land, industry, services, trade, facilities transportation, cemeteries, places of worship and other buildings [16]. An illustration of trends in agricultural and non-agricultural land use in the Purworejo Regency from 2009-2018 can be seen in the following Figure 3.

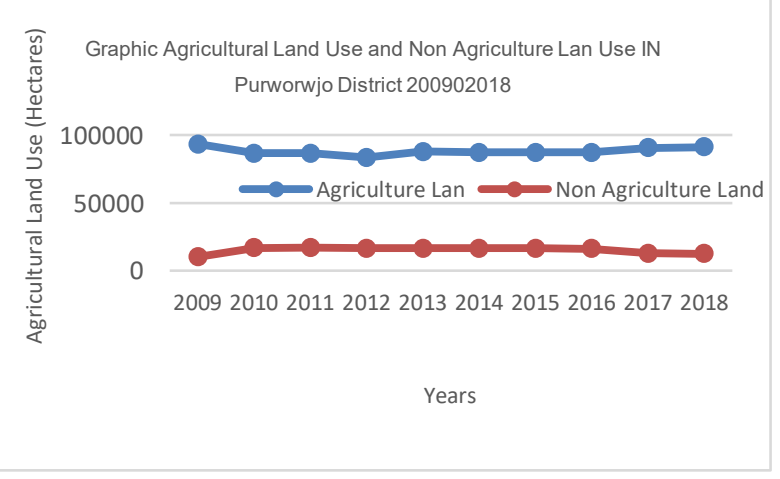

Fig. 3. Graphic agricultural land use and non agriculture land use in Purworejo Regency 2009-2018

In Figure 3 seen the trend of land use from 20092018 in the Purworejo Regency is still dominated by agricultural land use. When viewed from a trend pattern changes in breadth based on time widespread use of agricultural land in 2009 in Purworejo Regency was still high, but in 2010 there began to be a decline. Despite the decline in 2010, but in 2011 it slightly increased again.

Meanwhile, in 2012 the area of agricultural land use fell back to its lowest point, whereas from 2013-2018 the area of agricultural land continues to increase although relatively few. Meanwhile, for widespread changes in non-agricultural use, following the broad pattern of agricultural land use. This means that if the area of agricultural land use increases, the area of nonagricultural land use decreases and vice versa if the area of agricultural land use decreases, the area of nonagricultural land use increases. Although the trend of a significant decrease in the area of agricultural land use, occurred only until 2012 and has tended to increase again since 2013 due to the opening of agricultural land and the improvement of the irrigation network system so as to increase the area of agricultural land use.

However, the relatively small increase in agricultural land needs to be watched out for, because of the possibility of invasion of agricultural land for nonmining due to the development of Yogyakarta International Airport (YIA) Airport towards Purworejo and other socio-economic infrastructure developments. Agricultural land use is a dynamic land use, because agricultural land can change both in a fast and slow tempo. The change of agricultural land to nonagricultural land is strongly influenced by the physical condition of the land as well as social, economic and cultural aspects as well as government policies [1]. Trends in changes in land use are happening in the Purworejo Regency spatially it is quite varied. There are a number of sub-districts where the trend of wide changes in the use of agricultural land is very dynamic, but there are also those whose changes in area are very slow and do not even change. Trends in the variations in the spatial distribution of agricultural land use in Purworejo Regency by sub-district can be seen in Figure 4 below.

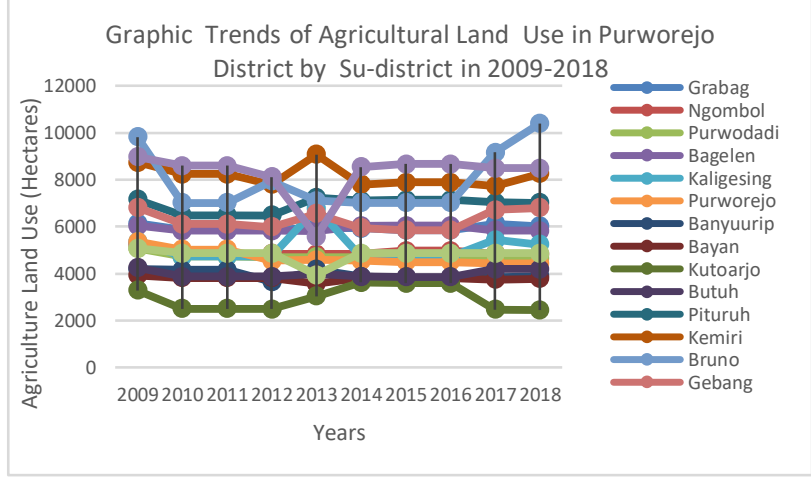

Fig. 4. Graphic trends of agricultural land use in Purworejo Regency by sub-district in 2009-2018

In Figure 4 we can see the spatial distribution trends extensive use of agricultural land from 2009-20018 in each sub-district in Purworeji Regency is quite varied. In 2009, area of agricultural land in all sub-districts in Purworejo Regency was still relatively high, but it started in 2010 throughout all sub-districts in Purworejo Regency agricultural land declined. The sub-district with the highest decline in agricultural land area in 2010 was found in Bruno Sub-district, while the lowest decrease was found in Banyuurip Sub-district. In 2013, the sub-district had the highest increase in agricultural land area is Kemiri and Kaligesing sub-districts, while the sharp decline is in Bener Sub-district and for other sub-districts experiencing relatively low fluctuations. Meanwhile, in 2017 the sub-district with a sharp decrease in Kutoarjo Sub-district, while the increase is 
quite sharp in the Bruno sub-district and for other subdistricts experiencing relatively low fluctuations. For 2018 the sub-district which has experienced a sharp increase since 2017-2018, namely the Bruno subdistrict, whereas the trend is decreasing, but not too sharp is the Kaligesing Sub-district, and for other subdistricts the fluctuation is relatively low.

Spatially the temporal variation in the increase and decrease in agricultural land is strongly influenced by variations in topographic conditions, increased population pressure on agricultural land, regional spatial planning policies, increased socioeconomic development and regional infrastructure [4]. For example, in 2010, Bruno sub-district although not an urban area, but has decreased the area of agricultural land because of damage to agricultural land due to landslides. Meanwhile, for urban areas such as in the Purworejo and Kotoarjo Sub-districts the decline in agricultural land is more due to population pressure, the provision of socio-economic infrastructure and because of changes in the function of spatial use. This means that in certain times and conditions, agricultural land in certain areas can undergo drastic changes if the factors that influence these changes are very strong [8].

\subsection{Trend spatial distribution of agricultural land carrying capacity}

Increased population density due to increasing population, both in rural and urban areas has resulted in an increase in the transfer functions of agricultural land for non-agricultural use such as for settlements or other uses. Population increase on the other hand will increase food needs even though the availability of agricultural land is increasingly narrow. These conditions resulted in the lower agricultural land carrying capacity.

A very dynamic increase in population will certainly have a big role in influencing the availability of agricultural land and the demand for agricultural production. An increase in population means an increase in land demand and ultimately causes high population pressure on agricultural land. This phenomenon occurs because the population always needs land to carry out economic activities in agriculture and non-agriculture. Increased use of agricultural land for non-agricultural economic activities. Increased use of agricultural land that will be used for economic activities in nonagricultural, will cause the area of land available for agricultural production activities will be reduced. If the phenomenon of declining agricultural land availability continues, it will gradually affect the decline in agricultural production. In fact, the number of people who need foodstuffs from agricultural production continues to grow every year. As a result, agricultural production will not be able to improve the welfare of farmers [1, 8]. Figure 6 shows distribution of the agricultural land carrying capacity in the Purworejo Regency.

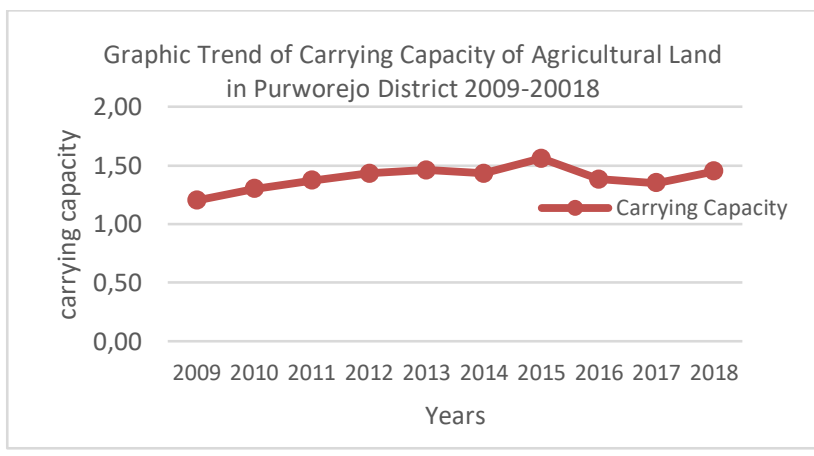

Fig. 5. Graphic trend of carrying capacity of agricultural land in Purworejo Regency 2009-20018

Figure 5 shows the trend of the carrying capacity of agricultural land in the Purworejo Regency from 20092019 tending to increase continuously even though it is fluctuating. The highest increase in the carrying capacity of agricultural land occurred in 2015 and the lowest decrease occurred in 2017. Although in Purworejo Regency the trend of the carrying capacity of agricultural land continued to increase from 2009-2018, but the value of the increase only ranged between $1 \leq \partial$ $\leq 2.46$. This means that the carrying capacity of agricultural land in Purworejo Regency from 2009-2018 is only able to be self-sufficient in food and unable to be a decent source of livelihood for its population.

This phenomenon needs to be watched out by the Purworejo Regency Government, because if this is allowed to happen slowly there will be a decrease in the carrying capacity of agricultural land. As a result, it will have an impact on the decline of agricultural land as a source of livelihood as well as a source of providing food needs for the population. Therefore, it is only natural for the government to adopt a policy to control land conversion and stipulating several sub-districts that still have high agricultural land carrying capacity to serve as sustainable agriculture areas.

Spatially, there appears to be a trend in the pattern of changes in the carrying capacity of agricultural land from 2009-2018 in each sub-district in Purworejo Regency which has a quite varied pattern of change. In Figure 6 to Figure 20, can be seen that have been several increases and decreases in the carrying capacity of the sub-districts since 2009-2018, but some have fluctuated and sloped. For example, one of the sub-districts experiencing a sharper increase in carrying capacity is Ngombol Sub-district, while those with fluctuating changes are found in Gebang Sub-district. Meanwhile, one sub-district whose changes were sloping was found in Kaligesing Sub-district. This phenomenon illustrates that the carrying capacity is very dynamic and is inseparable from the dynamics of population change and the area of agricultural land. 


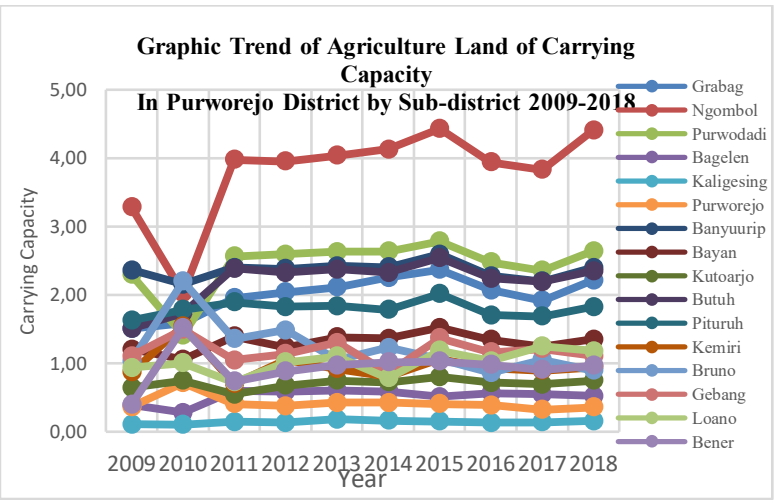

Fig. 6. Agriculture land carrying capacity trend of Purworejo Regency by sub-district in 2009-2018

Figure 6-10 the spatially temporal shows variations in the pattern of changes in the value of the carrying capacity of agricultural land in each sub-district from 2009-2018. In Figure 6-10, it appears that from 2009 to 2010, several sub-districts experienced a sharp increase and decrease in the carrying capacity of agricultural land. A quite sharp change was also seen in 2010 to 2011 , because there were a number of sub-districts in 2010 which decreased the value of agricultural land but rose very sharply in 2011. Conversely, there were also sub-districts whose carrying capacity rose in 2010 but declined sharply in 2011 However, there are also a number of sub-districts whose trend patterns of change from 2009 to 2011 are relatively stable, as shown in Bruno District. Meanwhile, from 2011-2018, the overall trend in the pattern of changes in the carrying capacity of agricultural land was relatively more stable. In fact, there are trends in several sub-districts whose change patterns are relatively more sloping than in 2009-2018.

Graph of Number of Sub-district According to the Carrying Capacity of Agriculture Land

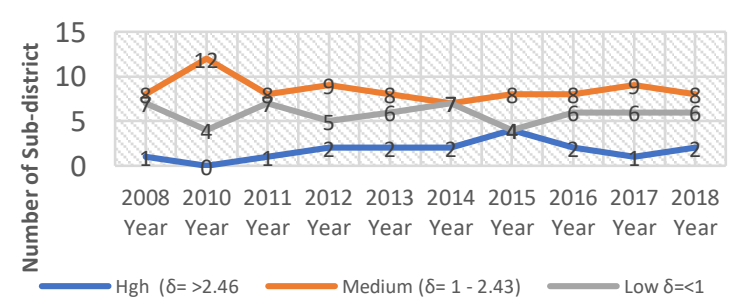

Fig. 7. Graph of number of sub-district according to the carrying capacity of Agriculture Land

Temporal spatial variation can also be seen from the results of the analysis of the categorization of the carrying capacity of agricultural land in each district from 2009-2018. The results of the analysis in Figure 7 shows the number of sub-districts that have a carrying capacity of $>2.46$ the amount is relatively very small. This can be seen from 16 districts at most there are only 4 districts that have a carrying capacity value of agricultural land $>2.46$ and then only occurred in 2015 . In fact, in 2010 none of the districts that had a carrying capacity value $>2.46$, while the trend of the number of sub-districts that have carrying capacity of agricultural land ranges from $1-\leq 2.46$ and $<1$ from 2009-2018 is quite a lot.
Based on trends in patterns of changes in the carrying capacity of agricultural land from 2009-2018 in each sub-district giving meaning that the sub-district area in Purworejo District has varying abilities in producing food to fulfill a decent living for the population. However, caution needs to be taken because, as seen as a whole, more sub-districts have a carrying capacity of agricultural land between $1-\leq 2.46$ and even the number of sub-districts with a carrying capacity $<1$ in number are also quite large compared to sub-districts that have a carrying capacity of $>2.46$. This vigilance is in line with the trend in the carrying capacity of agricultural land at the Purworejo Regency level, which is dominated by carrying capacity between $1-\leq 2.46$.

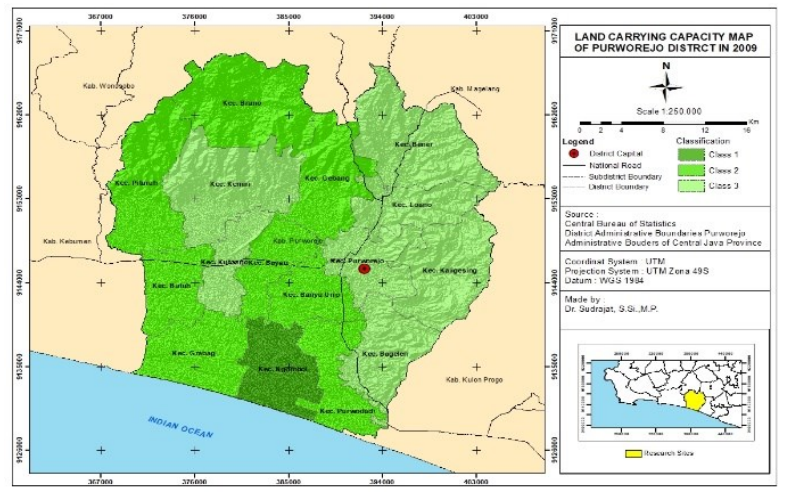

Fig. 8. Map of carrying capacity of agricultural land in Purworejo Regency in 2009

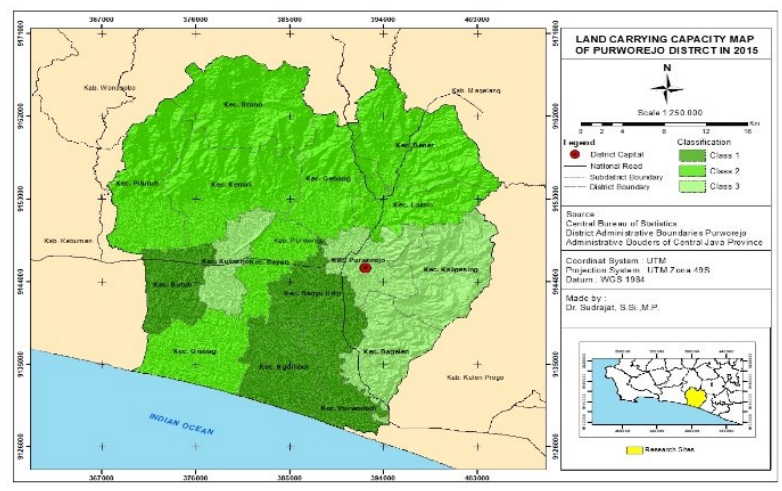

Fig. 9. Map of agricultural land carrying capacity in Purworejo Regency in 2015

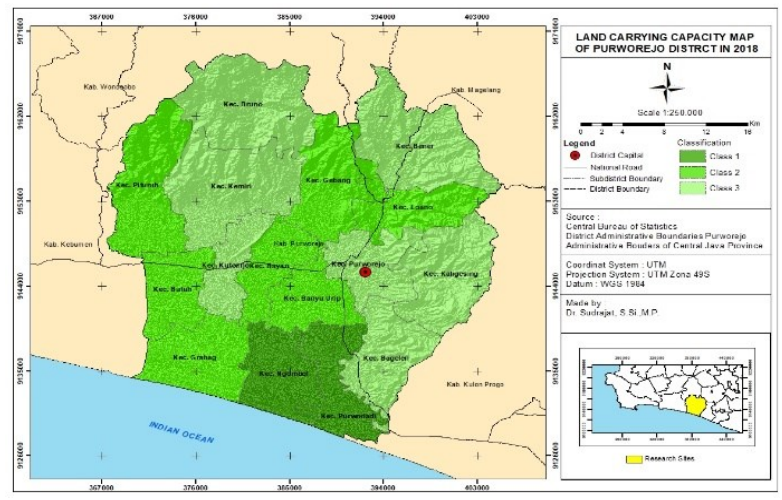

Fig. 10. Map of carrying capacity of agricultural land in Purworejo Regency in 2018 


\section{Conclusion}

Spatially the pattern of changes in the carrying capacity of agricultural land from 2009 to 2018 in each subdistrict in Purworejo Regency is quite varied, but there tends to be a slightly downward trend in several districts. Meanwhile, temporally the pattern of changes in the carrying capacity of agricultural land is highly fluctuating in 2009 to 2011, while starting from 2012 to 2018 it is relatively not so volatile. Temporal spatial variation in the pattern of change is closely related to variations in changes in agricultural land area, harvest frequency, land productivity and population in each district. If the trend of decreasing the carrying capacity of agricultural land is allowed to continue, it does not rule out the possibility of local food availability in each sub-district in Purworejo Regency will decline. Therefore, it is reasonable if the Government of Purworejo Regency adopts a policy to control changes in agricultural land that is increasingly rife.

On this occasion the authors would like to thank the UGM Publisher and Publication Board (PBB) for providing RTA 2020 Grant funds, so that the authors can attend the ICST 2020. The author also thanks the team of students who participated in data collection and preparation of this paper.

\section{References}

1. Sudrajat, IJG, 48,1:91-101 (2016).

2. I.D.G.A.D Putra, S.U. Made, I.G.W. Yasa, E-Jurnal Ekonomi dan Bisnis Universitas Udayana, 5,3:387402 (2016). [In Bahasa Indonesia]

3. L. Nurchamidah, Djauhari, Jurnal AKTA, 4,4:699706 (2017). [In Bahasa Indonesia]

4. Suhartini, Kajian Kearifan Lokal Masyarakat dalam Pengelolaan Sumber Daya Alam dan Lingkungan. (2019). https://eprints.uny.ac.id/ 12149/ accesed on Monday, February $15^{\text {th }} 2020$. [In Bahasa Indonesia]

5. Ridwan, Jurnal Studi Islam dan Budaya, 3,1:27-38 (2007). [In Bahasa Indonesia]

6. L. Muta'ali, Teknik Analisis Regional untuk Perencanaan Wilayah, Tata Ruang dan Lingkungan. Yogyakarta: Badan Penerbit Fakultas Geografi (BPPFG) Universitas Gadjah Mada (2015). [In Bahasa Indonesia]

7. C. Agustizar, Muryani, S. Sarwono. Agricultural Land Carrying Capacity and Shift of Land Use in Upstream of Grompol Watershed, Central Java Province. In : 1st UPI International Geography Seminar 2017 IOP Publishing. 2017. IOP Conf. Series: Earth and Environmental Science 145 (2018) 012070 doi :10.1088/1755-1315/145/1/01207.

8. Sudrajat, Suhendra, W. Arifa, Majalah Geografi Indonesia, 33, 2 (2020). [In Bahasa Indonesia]

9. S. Padjarajani, Majalah Geografi Indonesia, 22,2: 102-123 (2008). [In Bahasa Indonesia]

10. V.R.B. Moniaga, Jurnal Ilmiah Sosial Ekonomi Pertanian, 7,2:61-68 (2011). [In Bahasa Indonesia]

11. D. Moehar, Pengantar Ekonomi Pertanian. Jakarta. Bumi Aksara. 2002. [In Bahasa Indonesia

12. Riyadi, Bratakusumah, Perencanaan Pembangunan Daerah. Jakarta. PT Gramedia Pustaka Utama.
(2004). [In Bahasa Indonesia]

13. Sajogyo, P. Sajogyo, Sosiologi Pedesaan: Kumpulan Bacaan. Jilid 2. Jakarta. Gadjah Mada University Press. 1982. [In Bahasa Indonesia]

14. O. Soemarwoto, Tekanan Terhadap Lingkungan, Khususnya Lahan dan Tanggung Jawab Dunia Usaha dan Industri. Majalah Manajemen (1984). [In Bahasa Indonesia]

15. O. Soemarwoto, Ekologi, Lingkungan dan Pembangunan. Jakarta: Djambatan (2001). [In Bahasa Indonesia]

16. Badan Pusat Statistik, Kabupaten Purworejo Dalam Angka. Badan Pusat Statistik. BPS-Purworejo (2019). [In Bahasa Indonesia] 